\title{
PELAKSANAAN KEBIJAKAN KOMUNIKASI ORGANISASI PEMERINTAHAN DI INDONESIA
}

\author{
Arie Purnomo \\ Program Studi Ilmu Pemerintahan, FISIP, Universitas Muhammadiyah Sorong
}

\begin{abstract}
The research aim to know the application policy of organization communication which applied by government in Indonesia. These research applied on Government in Indonesia. The informant namely have relevant with task to give policy which must applied related with the policy of organization communication. Data analysis which collected it as well as primary and secondary data and further to arrange, to analysis, to interpretation then take of conclusion as the answe of problem. The result of research showed that organization communication have communicated by head of instance and job unit and subordinate it in application of main task and function in aim to task by Governor. The application of organization communication it created of organization climate which conducive in vertically, horizontal and diagonal by leader of job unit and subordinate in organization to applied of policy, main task and function which obligate it.
\end{abstract}

Keywords: Internal and External Organization Communication .

\section{PENDAHULUAN}

Dinamika organisasi yang selalu hidup dan berkembang selalu ditandai dengan iklim komunikasi organisasi yang baik. Aktualisasi dari iklim yang baik yaitu terciptanya komunikasi aktif dan efektif antara pimpinan dengan bawahan, antara bawahan dan rekan kerjanya, antara pimpinan, bawahan dan publik dalam suatu organisasi. Pembentukan iklim organisasi yang telah tergambar seperti diatas, diperlukan untuk mempercepat kegiatankegitan koordinasi, kerjasama dan pencapaian tujuan organisasi, untuk mewujudkan semua itu perlu diciptakan iklim komunikasi organisasi yang baik.

Memahami hal demikian, dalam kenyataan ada obyek yang akan diamati secara empiris menunjukkan bahwa lingkup Pemerintahan di Indonesia dalam penerapan iklim komunikasi antar organisasi memperlihatkan gejala iklim komunikasi organisasi yang belum efektif. Contohnya dari hasil observasi dan wawancara yang dilakukan pada pimpinan dan beberapa staf terlihat ada kesenjangan mis-komunikasi antara pimpinan dengan bawahan, bawahan dengan sejawatnya di antara unit kerja. Secara struktural, organisasi pemerintahan yang dipimpin oleh kepala dinas, dibantu oleh kelompok jabatan struktural dan kelompok jabatan fungsional belum terjalin iklim komunikasi organisasi yang baik.

$$
\text { Kenyataannya masih sering }
$$
ditemukan berbagai permasalahan dalam menjalankan tugas pokok dan fungsinya untuk memajukan organisasi. 
Permasalahan yang sering muncul saat ini adalah sering terjadi kesalahan komunikasi (mis-communication), komunikasi secara vertikal antara pimpinan dengan kelompok jabatan struktural dan fungsional sebagai bawahannya. Kesalahan komunikasi juga sering terjadi secara horizontal antara kelompok jabatan fungsional dengan kelompok jabatan fungsional (sesama bawahan) dalam menjalankan berbagai program dan kegiatan organisasi. Termasuk kesalahan komunikasi juga sering terjadi secara diagonal antara pimpinan dengan kelompok struktural/fungsional dan publik berkaitan dengan implementasi kegiatan pelayanan organisasi. Contoh secara vertikal, kepala dinas dengan kelompok jabatan struktural dan fungsional yang terkadang berselisih pendapat dalam pelaksanaan tugas pokok dan fungsi. Secara horizontal, sesama bawahan dalam pelaksanaan program dan kegiatan sering berselisih pendapat dalam mengkomunikasikanna. Dan secara diagonal antara pimpinan, bawahan dan publik yang dilayani tidak dapat mengkomunikasikan program kegiatan layanan secara terpadu.

Kekeliruan yang sering tejadi dalam komunikasi organisasi menjadi dampak menurunnya pertasi kerja dan kinerja pegawai dalam melaksanakan tugas pokok dan fungsinya dengan baik, oleh sebab itu perlu usaha untuk membudayakan iklim komunikasi organisasi yang efektif dengan memunculkan berbagai tindakan atau kegiatan komunikasi sesama pihak-pihak yang salaing berkomunikasi dalam suatu organisasi. Bentuk aktualisasi dari kegiatan komunikasi yang sering dilakukan adalah dengan sesering mungkin berbicara, berdiskusi, bertemu dan melakukan kerjasama dalam membahas bernagai program dan kegiatan yang berkaitan dengan pelaksanaan tugas kerja yang dipikul.

Disadari dalam kenyataan keseharian pada Pemerintahan di Indonesia, iklim komunikasi organisasi sering tidak berjalan efektif, karena pimpinan sering menerapkan komunikasi yang sulit diimplementasikan dan diterjemahkan oleh jabatan struktural dan fungsional dikarenakan frekuensi dan efektifitas komunikasi yang dilakukan tidak tersosialisasikan dengan baik.

Iklim komunikasi juga sering terabaikan diantara kelompok jabatan struktural dan fungsional dalam membahas berbagai program dan kegiatan. Diantara kelompok tersebut cenderung kurang berkomunikasi, bersifat kurang efektif dalam melakukan komunikasi baik secara pribadi, kelompok dan unit kerja, sehingga sering terjadi kevakuman dalam 
menjalankan tugas pokok dan fungsinya masing-masing dalam melakukan program dan kegiatan yang ditugaskan atau diwewenangkan.

Iklim komunikasi organisasi juga sering kurang terimplementasi dengan baik antara pimpinan dengan kelompok jabatan struktural/fungsional serta berbagai kalangan stakeholder atau publik dalam mengaplikasikan komunikasi berbagai program dan kegiatan pelayanan. Akibatnya program dan kegiatan yang dilakukan sering menuai protes, kritikan dan pengaduan dari berbagai pihak yang merasa tidak terlayani secara optimal, akibat kurang efektif dan efisien dalam melakukan penciptaan iklim komunikasi organisasi yang baik.

Terjadinya berbagai permasalahan terhadap iklim komunikasi organisasi efektif dan efisien ini dikarenakan oleh beberapa faktor yang dapat mempengaruhi. Faktor tersebut bisa berupa faktor pendukung dan faktor penghambat, sehingga iklim komunikasi organisasi mudah diterapkan atau sulit diterapkan. Faktor-faktor tersebut meliputi faktor pimpinan, tingkah laku SDM atau karyawan, kelompok kerja dan eksternal organisasi.

Pimpinan merupakan faktor yang bisa menjadi pendukung dan penghambat terbentuknya suasana komunikasi organisasi. Faktor pimpinan yang menjadi pendukung mempu memciptakan suasana komunikasi yang efektif dan efisien yang menciptakan keharmonisan dengan selalu berkomunikasi untuk memecahkan permasalahan organisasi. Pimpinan menjadi faktor penghambat bila pimpinan tidak mampu memecahkan masalah dan jarang mengkomunikasikan masalah kepada bawahannya yaitu kelompok jabatan struktural dan fungsional yang berkaitan dengan tugas pokok dan fungsinya.

Tingkah laku sumber daya manusia atau karyawan merupakan merupakan salah satu faktor yang menjadi pendukung dan penghambat terbentuknya iklim komunikasi organiasi. Tingkah laku karyawan menjadi faktor pendukung bila karyawan memiliki kompetensi dalam berkomunikasi memecahkan permasalahan organisasi dan perilaku karyawan menjadi penghambat bila karyawan tidak memiliki perilaku profesional dalam bekerja dengan baik menghadapi dinamika organisasi yang membutuhkan komunikasi.

Kelompok kerja merupakan salah satu faktor yang menjadi pendukung dan menghambat terciptanya iklim komunikasi organisasi. Bila kelompok kerja saling berkomunikasi dan bekerjasama menjalankan tugas pokok dan fungsinya, maka iklim komunikasi organisasi tercipta 
secara harmonis dan efektif, sebaliknya bila kelompok kerja kurang berkomunikasi dengan kelompok sendiri dan kelompok lain, maka iklim komunikasi organisasi tidak terwujud dengan efektif.

Termasuk faktor eksternal organisasi merupakan faktor pendukung dan penghambat terciptanya iklim komunikasi organisasi yang baik. Diharapkan faktor eksternal yang dimainkan oleh organisasi mampu menumbuhkan komunikasi dan kerjasama yang terjalin dengan baik dengan berbagai pihak, stakeholder atau publik agar tercipta komunikasi efektif dan hal ini menjadi faktor pendukung. Sebaliknya bila faktor eksternal sering mengalami kesalahan komunikasi atau frekuensi komunikasi kurang, maka aplikasi komunikasi tidak tercipta dengan baik dan ini menjadi faktor penghambat terciptanya iklim komunikasi organisasi yang baik.

\section{KAJIAN PUSTAKA}

Kata "komunikasi" berasal dari bahasa Latin, “comunis”, yang berarti membuat kebersamaan atau membangun kebersamaan antara dua orang atau lebih. Akar katanya "communis" adalah "communico" yang artinya berbagi (Stuart,1983, dalam Vardiansyah, 2004 : 3). Dalam literatur lain disebutkan komunikasi juga berasal dari kata "communication" atau "communicare" yang berarti " membuat sama" (to make common). Istilah "communis" adalah istilah yang paling sering di sebut sebagai asal usul kata komunikasi, yang merupakan akar dari kata Latin yang mirip komunikasi menyarankan bahwa suatu pikiran, suatu makna, atau suatu pesan di anut secara sama (http://cahpct.blogdetik.com/2009/04/02/de finisi-komunikasi/).

Dari uraian di atas, dapat disimpulkan bahwa komunikasi berasal dari akar kata yang maknanya selalu (1) melibatkan pertukaran simbol atau tanda baik verbal maupun nonverbal, terbangunnya relasi kebersamaan antara komunikator dengan komunikan. Simbol atau tanda verbal seperti bahasa lisan dan bahasa tulisan. Sementara simbol atau tanda nonverbal seperti mimic, gerak-gerik serta suara. Terbangunnya relasi kebersamaan ini bukan selalu sebagai hubungan yang positif seperti keakraban atau keintiman melainkan terbentuknya kontak hubungan antara pengirim pesan dengan penerima pesan melalui simbol atau tanda-tanda tertentu yang bersifat verbal atau nonverbal. Aplikasi kontak simbol ini baik dilakukan dengan diri sendiri (intrapersonal) maupun dengan pihak lain (antarpersonal).

Kehidupan manusia di dunia tidak dapat dilepaskan dari aktivitas komunikasi 
organisasi karena merupakan bagian integral dari sistem dan tatanan kehidupan sosial manusia dan masyarakat. Aktivitas komunikasi dapat dilihat pada setiap aspek kehidupan sehari-hari manusia yaitu sejak dari bangun tidur sampai manusia beranjak tidur pada malam hari. Bisa dipastikan sebagian besar dari kegiatan kehidupan menggunakan komunikasi baik komunikasi verbal maupun nonverbal. Namun, apa yang dimaksud dengan komunikasi itu sendiri.

Sardjono (2009:12) mencoba mendefinisikan komunikasi organisasi sebagai suatu proses dengan pesan dipindahkan atau dioperkan (lewat suatu saluran) dari suatu sumber kepada penerima dengan maksud mengubah perilaku, perubahan dalam pengetahuan, sikap dan atau perilaku overt lainnya. Sekurang-kurangnya didapati empat unsur utama dalam model komunikasi yaitu sumber (the source), pesan (the message), saluran (the channel) dan penerima (the receiver).

Wilbur Schramm (2009:212) menyatakan komunikasi organisasi sebagai suatu proses berbagi (sharing process). Schramm menguraikannya bahwa komunikasi berasal dari kata-kata (bahasa) Latin communis yang berarti umum (common) atau bersama. Apabila berkomunikasi, sebenarnya sedang berusaha menumbuhkan suatu kebersamaan (commonnes) dengan seseorang. Manusia berusaha berbagi informasi, ide atau sikap. Misalnya berusaha berkomunikasi dengan para pembaca untuk menyampaikan ide bahwa hakikat sebuah komunikasi sebenarnya adalah usaha membuat penerima atau pemberi komunikasi memiliki pengertian (pemahaman) yang sama terhadap pesan tertentu" (Suprapto, $2006: 2-3$ ).

Komunikasi merupakan aspek yang sangat penting bagi organisasi yang maju dan berkembang. Bagi suatu organisasi yang komunikasinya tidak efektif, akan berdampak adanya mis komunikasi yang menyulitkan organisasi mencapai tujuannya. Komunikasi dalam organisasi dibedakan atas komunikasi internal dan komunikasi eksternal (Haeruddin, 2006). Komunikasi organisasi pada prinsipnya adalah bentuk kegiatan yang dilakukan oleh setiap orang yang berkomunikasi dalam suatu organisasi. Biasanya komunikasi antar pimpinan dan bawahan, komunikasi antar bawahan dengan sejawatnya dan komunikasi suatu organisasi dengan organisasi lainnya (Lesmana, 2006).

Komunikasi dalam organisasi adalah suatu tindakan yang dilakukan oleh satu orang atau lebih yang berkomunikasi dengan cara mengirim, menginformasikan, 
menerima pesan, memberikan usulan, diskusi untuk menghasilkan sebuah umpan balik dalam menghasilkan pengertian dan tujuan yang sama. Karenanya dalam komunikasi organisasi tidak terlepas dari adanya komunikasi inter pribadi, antar pribadi, kelompok kecil, perilaku terbuka atau komunikasi massa yang dilakukan oleh pimpinan dan bawahan.

Komunikasi organisasi adalah suatu keterkaitan dalam berbagai pengembangan pesan yang disampaikan melalui sebuah saluran dari sumber pesan terhadap penerima pesan. Biasanya dalam suatu organisasi terdapat pihak sebagai sumber penerima informasi dan sebagai pemberi informasi untuk menghasilkan sebuah kompetensi organisasi yang efektif dalam mengolah pesan dan saluran sebagai umpan balik dan umpan maju dari efek komunikasi dalam memajukan organisasi (Spitzberg dan Cupach, 2009).

Komunikasi organisasi merupakan motif dari suatu tujuan orang yang berkomunikasi, yang dikemukakan secara sadar yang melibatkan banyak kepentingan sesuai dengan penggunaan media komunikasi yang efektif menghasilkan suatu komunikasi organisasi yang efektif tidak terlepas dari adanya komunikasi internal dan eksternal. Komunikasi internal dapat dilakukan secara vertikal, horizontal dan diagonal. Dan komunikasi eksternal dilakukan melalui pemberian informasi, diskusi dan kerjasama yang melibatkan adanya pembicaraan dengan menggunakan pesan yang mudah dimengerti (Reardon, 2007).

Komunikasi organisasi secara internal melibatkan suatu kegiatan pemberian pesan dan penerimaan pesan dari atasan terhadap bawahan atau orang lain, sehingga menghasilkan komunikasi internal secara vertikal, horizontal dan diagonal. Wujud komunikasi ini bervariasi sesuai dengan bentuk kegiatan organisasi di dalam menerapkan komunikasi organisasi yang efektif. Naisbitt (2004) menyatakan bahwa komunikasi organisasi internal secara vertikal yaitu tindakan komunikasi yang bersifat perintah, teguran, pujian dan petunjuk atas segala kegiatan yang dikomunikasikan untuk mencapai tujuan organisasi. Komunikasi organisasi internal secara horizontal yaitu tindakan komunikasi yang bersifat mediasi antar pimpinan, antar pegawai dan antar unit kerja dalam membicarakan sebuah kegiatan organisasi untuk mencapai tujuan. Komunikasi organisasi internal secara diagonal yaitu antara atasan dengan bawahan dan unit kerja yang saling berkomunikasi dalam memahami sebuah pesan yang diterima dan dikirim.

Memahami pentingnya komunikasi organisasi internal yang melibatkan unsur 
pimpinan, bawahan dan unit kerja sebagai suatu bagian yang tidak terlepas untuk menjadi bahan komunikasi organisasi. Efektifnya unsur-unsur komunikasi organisasi internal dalam mengkomunikasikan suatu permasalahan organisasi semakin memberikan kemudahan bagi organisasi tersebut untuk memecahkan permasalahan dalam mencapai tujuan organisasi (Rossy, 2008).

Selanjutnya komunikasi organisasi eksternal dapat dilihat dalam wujud komunikasi berupa komunikasi antar organisasi meliputi kegiatan umpan balik atas pemberian informasi, kegiatan kerjasama dan dialog antar organisasi. Nuhui (2005) menyatakan wujud komunikasi organisasi eksternal antar organisasi dalam berbagai umpan balik pemberian informasi biasanya diterapkan untuk saling memberikan bahan atau materi yang dibutuhkan oleh masingmasing organisasi dalam memudahkan menjalankan kegiatan organisasinya. Selain itu wujud dari komunikasi eksternal yaitu melakukan kerjasama dalam berbagai kepentingan untuk saling membenahi dan melengkapi kegiatan organisasi yang mengharuskan masing-masing organisasi untuk saling berdialog dalam memajukan dan memecahkan persoalan organisasinya. Dimensi-dimensi komunikasi organisasi yaitu pertama, komunikasi eksternal, digunakan anggota organisasi untuk interaksi dengan individu di luar organisasi. Komunikasi eksternal membawa pesan organisasi dan lingkungan organisasi yang relevan. Sistim pesan eksternal digunakan untuk menyampaikan informasi dari lingkungan organisasi dan untuk memberikan lingkungan informasi dari organisasi. Dan kedua, komunikasi internal, ialah pola pesan yang dibagi (share) antara anggota organisasi, interaksi manusia yang terjadi dalam organisasi dan antar anggota organisasi. Saat organisasi tumbuh pada ukuran atau kompleksitas atau menyebar keluar area dan zona waktu, ini memerlukan program komunikasi internal yang membantu membangun tim. Ini berarti komunikasi organisasi secara internal dan eksternal menjadi penting dalam mewujudkan bagaimana komunikasi yang tercipta dalam organisasi untuk mencapai tujuan organisasi.

Iklim organisasi merupakan salah satu hal yang memegang peranan penting di dalam kehidupan suatu organisasi. Iklim organisasi terdiri dari persepsi-persepsi atas unsur-unsur organisasi dan pengaruh unsur tersebut terhadap organisasi. Redding (1972) menyatakan bahwa iklim komunikasi organisasi sebagai kualitas pengalaman yang bersifat objektif mengenai lingkungan internal organisasi yang mencakup persepsi anggota 
organisasi terhadap pesan dan hubungan pesan dengan kejadian yang terjadi dalam organisasi. Iklim komunikasi organisasi menurut Suminar (1999:85) merupakan fungsi kegiatan yang menunjukkan kepada anggota organisasi bahwa organisasi tersebut mempercayai dan memberi kebebasan alam mengambil risiko, mendorong dan memberi tanggungjawab dalam mengerjakan tugas, menyediakan informasi yang terbuka dan cukup tentang organisasi dan mendengarkan dengan penuh perhatian serta memperoleh info yang dapat dipercaya dan terus terang dari anggota organisasi. Iklim komunikasi organisasi pada prinsipnya adalah bentuk kegiatan yang dilakukan oleh setiap orang yang berkomunikasi dalam suatu organisasi. Biasanya komunikasi antar pimpinan dan bawahan, komunikasi antar bawahan dengan sejawatnya dan komunikasi suatu organisasi dengan organisasi lainnya (Lesmana, 2006).

Iklim komunikasi dalam organisasi adalah suatu tindakan yang dilakukan oleh satu orang atau lebih yang berkomunikasi dengan cara mengirim, menginformasikan, menerima pesan, memberikan usulan, diskusi untuk menghasilkan sebuah umpan balik dalam menghasilkan pengertian dan tujuan yang sama. Karenanya dalam iklim komunikasi organisasi tidak terlepas dari adanya komunikasi inter pribadi, antar pribadi, kelompok kecil, perilaku terbuka atau komunikasi massa yang dilakukan oleh pimpinan dan bawahan.

Iklim komunikasi organisasi adalah suatu kondisi keterkaitan dalam berbagai pengembangan pesan yang disampaikan melalui sebuah saluran dari sumber pesan terhadap penerima pesan. Biasanya dalam suatu organisasi terdapat pihak sebagai sumber penerima informasi dan sebagai pemberi informasi untuk menghasilkan sebuah kompetensi organisasi yang efektif dalam mengolah pesan dan saluran sebagai umpan balik dan umpan maju dari efek komunikasi dalam memajukan organisasi (Spitzberg dan Cupach, 2009).

Iklim komunikasi organisasi merupakan kondisi dari suatu tujuan orang yang berkomunikasi, yang dikemukakan secara sadar yang melibatkan banyak kepentingan sesuai dengan penggunaan media komunikasi yang efektif menghasilkan suatu iklim komunikasi organisasi yang efektif tidak terlepas dari adanya komunikasi internal dan eksternal. Komunikasi internal dapat dilakukan secara vertikal, horizontal dan diagonal. Dan komunikasi eksternal dilakukan melalui pemberian informasi, diskusi bb dan kerjasama yang melibatkan adanya pembicaraan dengan menggunakan pesan yang mudah dimengerti (Reardon, 2007). 
Faktor yang mendukung dan menghambat iklim komunikasi organisasi menurut Higgins (1994:477-478) ada empat yaitu pimpinan, tingkah laku SDM, kelompok kerja dan eksternal organisasi. Pimpinan, pada dasarnya setiap tindakan yang diambil oleh pimpinan mempengaruhi iklim komunikasi organisasi dalam beberapa hal seperti aturan, kebijakan dan prosedur organisasi terkait dengan masalah yang berhubungan dengan masalah personalia, distribusi imbalan, gaya komunikasi, cara-cara yang digunakan untuk memotivasi, teknikteknik dan tindakan pendisiplinan, interaksi antara manajemen dan kelompok, interaksi antar kelompok, perhatian pada permasalahan yang dimiliki SDM dari waktu ke waktu, serta kebutuhan akan kepuasan dan kesejahteraan SDM.

Tingkah laku SDM, mempengaruhi iklim komunikasi organisasi melalui kepribadian yang ditunjukkan, terutama kebutuhan dan tindakan yang dilakukan untuk memuaskan kebutuhan tersebut. Komunikasi antar SDM memainkan bagian penting dalam membentuk iklim. Cara seseorang berkomunikasi menentukan tingkat sukses atau gagalnya hubungan manusia. Berdasarkan gaya normal seseorang dalam hidup atau mengatur sesuatu, dapat menambahnya menjadi iklim yang positif atau dapat juga menguranginya menjadi negatif.

Kelompok kerja, dalam hal ini terdapat kebutuhan tertentu pada kebanyakan orang dalam hal hubungan persahabatan, suatu kebutuhan yang seringkali dipuaskan oleh kelompok dalam organisasi. Kelompok-kelompok berkembang dengan dua cara yaitu secara formal, utamanya pada kelompok kerja dan informal sebagai kelompok persahabatan atau kesamaan minat. Eksternal organisasi mempengaruhi iklim komunikasi organisasi dilihat dari keadaan ekonomi sebagai faktor utama yang mempengaruhi iklim. Seperti tekanan untuk meningkatkan keuntungan, kebijakan pemerintah dalam menetapkan aturan dan penentuan upah.

\section{METODE PENELITIAN}

Penelitian ini dilaksanakan pada Pemerintahan di Indonesia. Waktu penelitian direncanakan selama 2 (dua) bulan yaitu mulai Februari sampai dengan Maret 2014. Jenis data yang digunakan dalam penelitian ini yaitu data primer adalah pengambilan data yang dilakukan dengan wawancara langsung dengan pihak yang berkompeten. Data sekunder adalah keseluruhan data hasil tanya jawab dengan responden terpilih berdasarkan pembagian kuesioner yang berisi pernyataan mengenai iklim komunikasi organisasi pada Pemerintahan di Indonesia. 
Peneliti memilih subyek penelitian dengan cara purposive yaitu pemilihan subyek secara sengaja oleh peneliti berdasarkan kriteria atau pertimbangan tertentu (Yin, 2005:67). Kriteria yang ditentukan peneliti bahwa subyek-subyek yang dipilih adalah mereka yang lebih mengetahui dan dapat memberikan informasi mengenai model pengembangan sumber daya manusia Pemerintahan di Indonesia, sehingga peneliti dapat memperoleh informasi sebagai data primer dalam penelitian ini.

Dalam menentukan subyek penelitian didahului dengan penentuan key informant yang membuka jalan untuk penelitian ini. Key informant merupakan orang yang paling berwenang dalam menentukan kebijakan yang harus dilaksanakan sehubungan dengan iklim komunikasi organisasi pada Pemerintahan di Indonesia dan merupakan orang yang menjadi kunci pokok untuk mendapatkan data primer, karena dengan pertimbangan bahwa orang yang dijadikan key informant lebih banyak mengetahui tentang masalah yang diteliti. Selanjutnya oleh key informant peneliti dibantu dalam menentukan subyek-subyek penelitian yang telah ditentukan, karena key informant lebih tahu orang-orang yang dapat memberikan data-data yang dibutuhkan peneliti untuk membahas permasalahan dalam penelitian ini.

Analisis data bertujuan untuk menyederhanakan data ke dalam bentuk yang lebih mudah dibaca dan dipahami, sehingga mencapai suatu kesimpulan yang tepat dan tersusun secara sistematis. M. Nazir (1999:419) menyatakan bahwa analisis data merupakan kegiatan-kegiatan untuk mengelompokkan, membuat suatu urutan, memanipulasi serta mengikat data, sehingga mudah dibaca. Dalam menganalisis data akan berlaku proses mengorganisasikan, mengurutkan data ke dalam pola, kategori dan satuan uraian dasar, sehingga dapat ditemukan tema dan dirumuskan kerangka kerja seperti yang disarankan oleh data. Pada penelitian ini, untuk menganalisis data yang telah terkumpul menggunakan teknik analisa data kualitatif, yaitu data yang telah dikumpulkan, dihimpun baik data primer maupun sekunder dan selanjutnya disusun, dianalisis, diinterprestasikan kemudian diambil kesimpulan sebagai jawaban atas masalah yang diteliti.

\section{HASIL DAN PEMBAHASAN}

Penerapan komunikasi organisasi yang diterapkan pada Pemerintahan di Indonesia yaitu melalui komunikasi vertikal, horizontal dan diagonal. Pada prinsipnya, komunikasi vertikal yang dilakukan pada Pemerintahan di Indonesia 
yaitu komunikasi antara pimpinan, unit kerja dan bawahan dalam bentuk pesan, perintah, teguran dan solusi. Prinsip yang diterapkan untuk komunikasi horizontal dilakukan antara pimpinan, unit kerja dan bawahan dalam bentuk komunikasi berdasarkan kegiatan kerja yaitu masukan, pengolahan dan hasil kerja yang telah dikomunikasikan. Sedangkan prinsip yang diterapkan untuk komunikasi diagonal yaitu melakukan komunikasi yang melibatkan semua unsur organisasi untuk memecahkan permasalahan organisasi melalui komunikasi internal organisasi.

Pelaksanaan komunikasi organisasi dari atasan ke bawahan yang terdiri dari beberapa kegiatan yang dilakukan oleh pimpinan kepada unit-unit kerja dan bawahan yang akan dikomunikasikan dengan cara pesan, perintah, teguran dan solusi atas berbagai yang dilakukan oleh unit-unit kerja dan para bawahannya. Seperti melakukan komunikasi internal dengan menjalankan aktivitas kerja. Pimpinan memanggil semua unit kerja dan para staf untuk mengkomunikasikan halhal yang berkaitan pelaksanaan tugas pokok dan fungsi.

Hasil komunikasi organisasi internal secara horizontal antara pimpinan, unit kerja dan bawahan diterapkan tepat sasaran yaitu pengembangan kerjasama dan peran serta masyarakat. Selanjutnya komunikasi organisasi internal secara horizontal yang intensif ditearpkan melalui kegiatan perlindungan, pemeliharaan, pemugaran benda cagar budaya, pembinaan pengelolaan museum, sejarah dan nilai tradisional serta usaha ketahanan budaya daerah. Untuk itu pimpinan dalam mengarahkan bawahannya dalam hal ini pegawai untuk mampu menyusun rencana kegiatan bidang sejarah dan purbakala sebagai pedoman dalam pelaksanaan tugas, mendistribusikan dan memberi petunjuk pelaksanaan tugas kepada bawahan agar pelaksanaan berjalan lancar. Selanjutnya melakukan pendistribusian dan memberi petunjuk pelaksanaan tugas, memantau, mengawasi dan mengevaluasi pelaksanaan tugas dan kegiatan bawahan.

Selanjutnya komunikasi organisasi internal secara diagonal yang diterapkan melibatkan semua unsur yang terlibat dalam berbagai kegiatan dan program kerja. Seperti komunikasi organisasi diagonal yang diterapkan yaitu pelaksanaan tugas pokok dan fungsi dari masing-masing unit seperti tugas pokok dan fungsi yang dikomunikasikan kepada setiap pimpinan unit kerja dan bawahannya untuk mendukung tugas tersebut.

Komunikasi organisasi kedalam secara sejajar telah diterapkan dengan melakukan komunikasi yang melibatkan pimpinan-pimpinan unit kerja dalam 
mengintruksikan perinta dari atasan kepada masing-masing jajarannya khususnya yang berkaitan dengan pelaksanaan tugas pokok dan fungsi untuk melaksanakan berbagai program dan kegiatan yang melibatkan masing-masing unit kerja.

Komunikasi organisasi internal secara diagonal telah diterapkan dengan melakukan komunikasi organisasi pada seluruh elemen organisasi mulai dari jajaran pimpinan, unit kerja dan bawahan untuk mengkomunikasikan berbagai hal yang berkaitan dengan pelaksanaan tugas dan fungsi masing-masing unit kerja. Komunikasi ini dilakukan untuk membantu pelaksanaan tugas yang diemban oleh kepala dinas dan unit kerja lainnya.

Pelaksanaan kebijakan komunikasi organisasi telah diterapkan secara vertikal, horizontal dan diagonal. Pelaksanaan komunikasi vertikal diterapkan melalui untuk pengembangan kerja, di mana yang dikomunikasikan secara vertikal yaitu pelaksanaan program pengadaan, peningkatan dan perbaikan sarana dan prasarana. Memahami komunikasi organisasi internal pada dasarnya memahami bagaimana organisasi melakuan komunikasi dalam memberikan pesan dan menerima pesan yang melibatkan unsur-unsur yang berkomunikasi dalam organisasi yaitu pimpinan, tim kerja dan bawahan.
Komunikasi organisasi internal yang diterapkan oleh setiap unsur organisasi menjadi sebuah perhatian dan pertimbangan untuk memahami arti penting komunikasi yang diterapkan dalam suatu organisasi. Semakin terjalin komunikasi internal yang efektif, semakin memudahkan setiap unsur yang berkepentingan dalam organisasi mudah meraih kemajuan dan pencapaian tujuan. Komunikasi organisasi internal yang efektif, yaitu terlibatnya seluruh komponen organisasi mulai dari pimpinan, unit kerja dan bawahan untuk saling memberikan informasi dan mengelola pesan untuk mencapai tujuan. Berarti komunikasi organisasi berperan penting terhadap keberhasilan organisasi.

Keberhasilan suatu organisasi tidak terlepas dari pentingnya komunikasi organisasi eksternal yang diterapkan. Penerapan suatu komunikasi eksternal dibangun atas adanya komunikasi timbal balik. Wujud komunikasi eksternal secara timbal balik berupa pemberian informasi, kegiatan kerjasama dan dialog antar organisasi. Dalam mengelola sebuah organisasi diperlukan suatu tindakan dari pimpinan untuk mengambil kebijakan dalam berkomunikasi dengan pihak luar atau eksternal organisasi. Ini dimaksudkan dalam rangka menjalin adanya hubungan komunikasi yang aktif diantara dua atau 
lebih organisasi yang melakukan komunikasi. Wujud komunikasi organisasi eksternal yaitu mengkomunikasikan lebih dari satu bentuk kepentingan atau kebutuhan organisasi yang satu dengan organisasi lainnya. Pada prinsipnya, suatu organisasi melakukan komunikasi aktif dengan organisasi yang lainnya untuk melakukan tukar informasi, menjalin kerjasama dan untuk berdialog memecahkan persoalan bersama.

Gambaran sebuah komunikasi organisasi eksternal yang efektif yaitu adanya kepentingan, kerjasama dan tujuan yang ingin dicapai. Melalui komunikasi antar organisasi akan menghasilkan sebuah pencapaian tujuan berdasarkan kepentingan dan kebutuhan. Devito (2011) menyatakan komunikasi organisasi merupakan channel penting untuk mencapai tujuan organisasi.

Ini berarti, suatu organisasi yang menerapkan komunikasi organisasi eksternal pada dasarnya didasari oleh tiga aspek yang ingin dicapai yaitu: 1) melakukan komunikasi untuk mencapai kepentingan, 2) berkomunikasi untuk bekerjasama, dan 3) berkomunikasi untuk mencapai tujuan. Ketiga hal ini diimplementasikan dalam wujud komunikasi dengan saling memberi informasi, menjalin kerjasama dan melakukan dialog untuk menuntaskan berbagai permasalahan dan manfaat dari aktivitas organisasi. Keberhasilan organisasi yang berbasis pada komunikasi organisasi eksternal yaitu selalu mengutamakan terjalinnya komunikasi yang efektif melalui pertukaran informasi antar organisasi, melakukan atau menjalin kerjasama dalam berbagai urusan atau program dan melakukan pembahasan melalui dialog atau simulasi untuk memecahkan adanya perbedaan diantara organisasi tersebut untuk lepas dari permasalahan. Melalui komunikasi organisasi secara eksternal, setiap komponen dari organisasi baik pimpinan, unit kerja dan bawahan, dapat melakukan kerjasama dengan organisasi lain melalui sebuah komunikasi yang aktif dan pro aktif untuk mengembangkan komunikasi eksternal. Komunikasi yang efektif yaitu komunikasi melalui kerjasama antar dua organisasi yang dijalin berdasarkan adanya komunikasi yang progresif, intensif, transparan dan akuntabel. Komunikasi organisasi eksternal yang sering diimplementasikan oleh beberapa organisasi yaitu melalui sebuah kegiatan yang bersifat dialog antar organisasi. Kegiatan komunikasi dialog ini dapat dilakukan melalui komunikasi antar pimpinan, antar unit kerja dan antar bawahan atau dapat dilakukan dengan massal melalui seminar, sarasehan, 
ataupun hal-hal yang berkaitan dengan kebutuhan untuk mengkomunikasikan dua organisasi yang biasanya dilakukan sesuai kesepakatan.

Komunikasi dalam organisasi adalah komunikasi di suatu organisasi yang dilakukan pimpinan, baik dengan para pegawai maupun dengan khalayak yang ada kaitannya dengan organisasi, dalam rangka pembinaan kerja sama yang serasi untuk mencapai tujuan dan sasaran organisasi. Manajemen sering mempunyai masalah tidak efektifnya komunikasi. Padahal komunikasi yang efektif sangat penting bagi para manajer, paling tidak ada dua alasan, pertama, komunikasi adalah proses melalui mana fungsi-fungsi manajemen mulai dari perencanaan, pengorganisasian, pengarahan dan pengawasan dapat dicapai; kedua, komunikasi adalah kegiatan dimana para manejer mencurahkan sebagian besar proporsi waktu mereka.

\section{KESIMPULAN}

Berdasarkan hasil penelitian dan pembahasan, disimpulkan penerapan komunikasi organisasi yang diterapkan pada Pemerintahan di Indonesia telah dikomunikasikan oleh Kepala Dinas beserta jajaran unit kerja dan bawahannya dalam menjalankan tugas pokok dan fungsi dalam membantu tugas kepemimpinan Gubernur. Penerapan komunikasi organisasi tersebut untuk menciptakan iklim organisasi yang diterapkan secara vertikal, horizontal dan diagonal oleh pimpinan unit kerja dan bawahannya dalam organisasi untuk melaksanakan kebijakan, tugas pokok dan fungsi yang diwawenangkan.

Pelaksanaan kebijakan komunikasi organisasi pada Pemerintahan di Indonesia tidak terlepas dari faktor-faktor yang menunjang dan menghambat. Faktor tersebut adalah faktor pimpinan, tingkah laku sumberdaya, kelompok kerja dan eksternal organisasi. Menjadi faktor pendukung, apabila pimpinan senantiasa mengkomunikasikan setiap program dan kegiatan kepada bawahannya, pegawai sebagai SDM saling berkomunikasi untuk kelancaran tupoksi, demikian halnya antar kelompok kerja untuk saling berkoordinasi dan selalu menjalin komunikasi yang baik dengan berbagai pihak di luar organisasi. Menjadi faktor penghambat apabila pimpinan, pegawai, kelompok kerja dan eksternal organisasi menunjukkan sikap individualisme, tidak saling berkomunikasi dalam pelaksanaan kegiatan dalam suatu organisasi.

\section{SARAN}

Dalam rangka pelaksanaan kebijakan komunikasi organisasi pada 


\section{Jurnal Noken $3(2) \quad \mathbf{2 0 1 8}$}

Pemerintahan di Indonesia, maka peneliti memberikan saran perlu ditingkatkan dan diperbaiki penerapan komunikasi organisasi yang selama ini diterapkan dengan menghindari adanya salah komunikasi dalam menerima wewenang kebijakan dan pelaksanaan tugas pokok dari masing-masing yang terlibat untuk menciptakan iklim komunikasi yang kondusif pada organisasi pemerintahan.

Perlu ditingkatkan dan dijalin suatu pemahaman tentang pentingnya komunikasi organisasi pada Pemerintahan di Indonesia untuk menjalankan program dan kegiatan yang telah dikomunikasikan secara vertikal, horizontal dan diagonal. Menjadi referensi untuk peneliti lanjutan yang minat mengkaji mengenai komunikasi organisasi pada obyek penelitian lainnya.

\section{DAFTAR PUSTAKA}

Effendy, Onong Uchjana, 2009. Komunikasi Teori dan Praktek, Bandung: Remaja Rosdakarya.

DeVito, Joseph A., 1989, Komunikasi antar manusia (edisi kelima), Profesional Books, Jakarta 1986. The Interpersonal Communication. $4^{\text {th }}$ Edition. New York : Harper and Row Publisher
2011. Komunikasi

Antar Manusia. Edisi Kelima, Penerbit Karisma Publishing Group.

Haeruddin, 2006. Komunikasi dan Pengkomunikasian. Penerbit Rajawali Press, Jakarta.

Kortel, Tubbs, SL, 2005, Human Communication, Fourth Edition. Random House Inc .New York.

Spitzberg, Danielson and Cupach, T, 2009. Communication Model and Practices. Published by Prentice Hall, New York.

Rossy, Harold, 2008, Theories Of Human

Communication, Fifth Edition,

Wadsworth Publishing Company, California.

Lesmana, Mulyana, D, 2006, Ilmu Komunikasi Suatu Pengantar, Edisi ke 6, Rosdakarya, Bandung.

Naisbitt, Marethen, Jr., 2004. Communication in Definition of Concept. Published by John Wiley and Sons, New York.

Nuhui, Muspida, 2005. Penerapan Komunikasi dan Bentuk-bentuk Komunikasi Efektif. Penerbit Dian Sarana, Surabaya.

Nurudin Tannen, 2004, Seni Komunikasi Efektif: Membangun Relasi Dengan Membina Gaya Percakapan, (alih 
bahasa dra. Amitya Komara), PT

Gramedia Pustaka Utama, Jakarta.

Pace, Don R. Wane, dan Faules, F, 2001.

Communication Organization.

Published by John Wiley and Sons,

New York.

2006.

Communication Organization in

Government. Published by John

Wiley and Sons, New York.

Purwanto, Andrik., 2006. Komunikasi

Multikultural. Cetakan Ke-1.

Surakarta.

Reardon Berlo, SA, S.J. 1987. Interpersonal Communication,

Relating to Others, Allyn and

Bacon. Boston.

Ruslan, A.F., 2002. Manajemen, Erlangga, Jakarta.

Sarwoto, Adi, 1999. Sosiologi Organisasi,

Citra Aditya Bakti, Bandung.

Sendjaja, Sasa Djuarsa, 2009. Pengantar

Komunikasi. Jakarta: Universitas

Terbuka.

Suprapto, Tommy, 2006. Pengantar Teori

Komunikasi. Cetakan Ke-1.

Yogyakarta: Media Pressindo.

Sutarto, 2004. Aspek Manusia Dalam

Organisasi, Penerbit Erlangga,

Jakarta.

Vardiansyah, Dani, 2004. Pengantar Ilmu

Komunikasi. Cetakan Ke-1. Bogor:

Ghalia Indonesia.
Walber, John, 2006, Theories of Human

Communication, Belmont,

California: Wadsworth Publishing Company.

Yumi, Wiryanto, 2006, Pengantar Ilmu Komunikasi, Jakarta:PT

RajaGrafindo Persada.

\section{Internet:}

“Definisi Komunikasi.” Blogdetik.com. 11

Juni 2010.

<http://cahpct.blogdetik.com/2009/

04/02/definisi-komunikasi/>

Riswandi. "Definisi Komunikasi dan Tingkatan Proses Komunikasi.” WordPress.com 17 Oktober 2006. $10 \quad$ Juni 2010. <http://meiliemma.wordpress.com/ 2006/10/17/definisi-komunikasidan-tingkatan-proses-

komunikasi/>.

Zubair, Agustina. "Definisi Komunikasi." WordPress.com 17 Oktober 2006. $10 \quad$ Juni 2010. <http://meiliemma.wordpress.com/ 2006/10/17/definisi-komunikasi>. 